AMICHAI, Yehuda. Terra e paz: antologia poética. Organização e tradução: Moacir Amâncio. Rio de Janeiro: Bazar do Tempo, 2018. 183p.

\title{
Coração e museu
}

\section{Luiz Lopes*}

Centro Federal de Educação Tecnológica de Minas Gerais (CEFET-MG) I Belo Horizonte, Brasil

luigilopes@gmail.com

Em "Amor pelo país", um dos poemas que figuram na primeira antologia poética de Yehuda Amichai, traduzida e publicada no Brasil, podemos ler: “O país está dividido em distritos da memória e regiões da esperança/ seus habitantes misturam-se uns aos outros, / como se voltassem de um casamento/ junto com quem retorna de um funeral". ${ }^{1}$ Essa imagem de um país dividido, assim como dos afetos indecidíveis, ou, de outros pares antitéticos como terra/paz, perpassam os textos do escritor judeu e sublinham o pensamento poético do escritor. Além disso, essa tensão entre vida e morte, paz e guerra, alegria e melancolia, presente e passado faz dos poemas de Amichai uma espécie de exercícios de aproximação e de redenção pela memória.

Amichai nasceu em 1924, em Würzburg, Alemanha. Seu primeiro nome foi Ludwing Pfeufer, mas, após a Segunda Guerra Mundial, migrou com sua família para a Palestina, trocando seu nome para Yehuda Amichai como forma de afastar as lembranças de humilhações vividas no passado. Amichai carrega o sentido de "meu povo vive" e, em grande medida, as poesias do escritor são essa tentativa de sobrevivência, tentativa de dar a ver as pequenas luzes que sobrevivem tal como afirma Georges Didi-Huberman em Sobrevivência dos vaga-lumes.

Considerado como o poeta mais importante de Israel no que tange ao nacionalismo, Amichai recebeu diversos prêmios e foi traduzido para mais de 40 idiomas. O poeta faleceu em 2000 e sua poesia chega agora ao público brasileiro, quase 20 anos depois de sua morte, testemunhando a presença de um autor interessado em refletir sobre a memória e efetuar uma defesa da esperança e de um mundo pacificado.

\footnotetext{
* Professor do Centro Federal de Educação Tecnológica de Minas Gerais e Doutor em Estudos Literários pela Universidade Federal de Minas Gerais.

${ }^{1}$ AMICHAI, 2018, p. 56. 
Terra e paz foi organizada e traduzida por Moacir Amâncio e publicada pela editora Bazar do tempo. A edição é bem cuidada e conta com um texto introdutório do próprio tradutor, "Para bagunçar a bíblia: Yehuda Amichai e a reinvenção da tradição". Nesse texto introdutório, Moacir Amâncio, seu tradutor, sublinha alguns aspectos da poesia e da biografia do poeta.

Amichai, que carregou consigo a memória do nazismo, integrou o exército britânico na Segunda Guerra, lutou na Guerra da Independência - deflagrada pelos países árabes após a fundação do Estado judaico em 1948 -, participou da Guerra do Sinai em 1956, da Guerra do Yom Kipur em 1973, ao mesmo tempo em que se tornava professor, atividade exercida durante toda a sua vida profissional, ao lado da literatura. Na trajetória do poeta, o idioma alemão o acompanhou à sombra, assim como as memórias da infância, como a pequena Ruth, amiga do poeta quando garoto, que foi assassinada num campo de extermínio. O hebraico, no entanto, o acompanhou desde a infância ortodoxa, na escola e nas orações em casa e na sinagoga, o que, é claro, propiciou a adaptação a Israel e ao idioma que aos trancos transforma-se numa das línguas faladas e escritas da humanidade, após tanto tempo de silêncio, fato único na história até o momento. Israel também é isso: resultado da reunião de judeus procedentes de cem países, com idiomas e culturas próprias, dando origem a um país tão reduzido quanto matizado. ${ }^{2}$

Ao lermos o conjunto de poemas de Amichai, percebemos alguns traços apontados nesse trecho. O primeiro deles é o fato de que estamos diante de uma poesia da memória, como aparece em poemas como "Esquecer alguém", "O homem não tem tempo" e "Meu pai esteve". Cada um desses textos, para ficarmos em poucos exemplos, elabora uma reflexão sobre a dor do passado, sobre objetos perdidos, mas também sobre a possibilidade de escrever como gesto de luta e resistência ao esquecimento fácil. É nessa linha de reflexão que se insere o poema "A pequena Ruth":

Às vezes eu me lembro de ti, pequena Ruth,

que nos separamos na infância longínqua, que te queimaram nos campos.

Se estivesses viva agora, serias uma mulher de sessenta e cinco anos,

mulher à beira da velhice. Aos vinte foste queimada,

${ }^{2}$ AMÂNCIO in AMICHAI, 2018, p. 13. 
eu não sei o que aconteceu na tua vida curta

desde que nos separamos. O que conseguiste, que considerações

colaram nos teus ombros, nas tuas mangas, na

tua alma corajosa, que estrelas brilhantes

pregaram em ti, que sinais de bravura, que

medalhas de amor penduraram no seu pescoço,

em que paz descansas, que estejas em paz.

O que aconteceu nos teus anos de vida não usados?

Acaso eles ainda estão embrulhados como pacotes bonitos,

Acaso somaram-se à minha vida? Acaso me trasnformaste

no banco do teu amor como os bancos da Suíça

onde o tesouro fica guardado após a morte de seus proprietários.

Acaso eu deixarei tudo isso de herança aos meus filhos que jamais viste?

Tu me deste a tua vida, como um vendedor de vinho embriagador - mas ele permanece sóbrio,

tu, sóbria na morte, lúcida na treva, deste

a um bêbado de vida como eu, chafurdando no seu esquecimento.

Às vezes eu me lembro de ti em momentos

Imprevistos e em locais que não se destinaram à lembrança, mas para o que não dura, vai embora, não permanece, como no aeroporto quando os viajantes que chegam param cansados ao lado da esteira rolante que gira com as bagagens, os pacotes deles, e eles descobrem o que lhes pertence com gritos de alegria como na ressureição dos mortos, e saem rumo às vidas deles. Aquela mala que volta de novo desaparece retoma, lentamente, no salão que se esvazia, de novo, de novo ela passa.

Assim passa a tua imagem tranquila por mim, assim eu me lembro de ti, até que a esteira pare de girar. E fique imóvel, assim seja. ${ }^{3}$ 
Assim como outros poemas da antologia, "A pequena Ruth" é construído a partir das tensões entre o dever de memória e a possibilidade de um esquecimento feliz. Só é possível esquecer alguém que amamos, no entanto, a partir do horizonte da nossa própria morte. É por isso que, nesse poema como em outros da coletânea, a memória é convocada como ato de vida e o esquecimento parece ser aquilo que também é inevitável para o exercício da vida, a saber, a extinção de uma memória particular que se perde quando cada humano deixa o mundo. Nesse poema, há a reflexão sobre a lembrança, o passado e o esquecimento tão presentes na poesia de Amichai e há também outra linha de força que atravessa o livro, uma espécie de elogio ao amor, que, no caso desse poema em particular é, antes de tudo, filia, amizade.

Essa linha aparece, do mesmo modo, em poemas como "O amor de Jerusalém" e "Amantes deixam impressões digitais". No primeiro poema, o amor é direcionado ao território da cidade, às ruas, mas, sobretudo, à construção de um espaço matizado, como afiança Amâncio ao falar de Israel. É esse lugar de contradições, carregado de tensões, que parece despertar o amor do eu lírico. Ele contrapõe o amor de quem passa pelas ruas da cidade com o amor daqueles que amam a cidade pela leitura ou pelo contato com os livros: "Mas quem ama Jerusalém/segundo os livros de turismo e oração/ é como quem ama uma mulher/segundo os livros de posições eróticas". ${ }^{4}$ Já no segundo poema, há uma espécie de figuração do desejo erótico e da presença mais abrangente do amor entre os corpos. O que interessa, contudo, é como a linha da memória se cruza com a linha do elogio ao amor. O título do poema já assinala para o leitor as relações entre amor e memória. Temos, assim, lembrança daquilo que amamos. E porque amamos deixamos pegadas, marcamos objetos, deixamos restos e rastros, que testemunham nossa presença e falam de nossa identidade: "Amantes deixam impressões digitais um no outro,/ muitas provas,/ palavras sem fim,/ testemunhas,/ a roupa amassada,/ um jornal com a data exata,/ relógio e relógio $[\ldots]^{\prime \prime} .^{5}$

Por fim, cabe dizer que a poesia de Yehuda Amichai chega até nós para que possamos conhecer um poeta indispensável e uma obra que faz pensar no trabalho infinito da memória e do amor, como também no trabalho infinito de construção do próprio eu. Essas qualidades da poesia de Amichai parecem suficientes para que haja interesse pela leitura ruminante de cada um de seus poemas. $\mathrm{O}$ autor nos convida para essa tarefa, que precisa ser demorada, do seu pensamento matizado. A antologia se encerra com um poema intitulado "Poema infinito". Poesia, vida e

\footnotetext{
${ }^{4}$ AMICHAI, 2018, p. 26.

${ }^{5}$ AMICHAI, 2018, p. 40.
} 


\section{Arquivo Maaravi}

pensamento são exercícios intermináveis para o poeta que elege a imagem de um coração museu. "Dentro do museu/uma sinagoga, dentro dela/ eu/ dentro de mim/ meu coração, / dentro do meu coração/ museu". ${ }^{6}$ Novamente, o que aparece nesses versos é a lógica não binária entre os movimentos do coração e do passado imóvel. Ao justapor o coração, a vida e os movimentos típicos do órgão do amor, mas também da memória, guardar de cor, de coração, ao museu, esse signo do passado, da conservação, Amichai convida a pensar num museu vivo, assim como num coração que um dia será apenas recordação.

Recebido em: 13/09/2019.

Aprovado em: 23/09/2019. 